INTERNATIONAL JOURNAL OF RESEARCHES IN BIOSCIENCES, AGRICULTURE AND TECHNOLOGY (c) VISHWASHANTI MULTIPURPOSE SOCIETY (Global Peace Multipurpose Society) R. No. MH-659/13(N) www.vmsindia.org

\title{
STUDY OF GROWTH, SPORULATION AND OTHER PARAMETERS OF SELECTED SEED BORNE FUNGI OF SPINACH
}

\author{
D. M. Survase \\ Dept. of Botany, K.R.A. College, Deola Dist. Nashik (M.S.) \\ damusurvase@gmail.com
}

\begin{abstract}
:
As a seeds are living and on storage of them affect its germination and viability. Different vegetable seed borne pathogen was studied by Richardson (1990) and isolated more than 50 microorganisms associated with it. Destruction of stored seeds was carried out by many microorganisms.

In the present investigation seed borne fungi of spinach was studied and 14 fungal sps. i.e. Aspergillus flavus, A. niger, Phomopsis vexans, Drechslera longirostrata, Rhizopus stolonifer, Colletotrichum dematium, Macrophomina phaseolina, Curvularia lunata, Cladosporium sp., Alternaria tenuis, Fusarium moniliforme, Aspergillus candidus, Penicillium sps, Mucor sp, were isolated and identified. Out of these very common four fungal species Aspergillus niger, Curvularia lunata, Drechslera longirostrata and Fusarium moniliforme were brought into pure culture and used for further studies. Effect of some common medicinal plants tested against incident of seed mycoflora, seed germination, dry mycelial weight and TPC (Total Phenol Content) of root biomass of selected medicinal plants was determined invitro. Overall Semecarpus anacardium, Solanum xanthocarpum and Abrus precatorius root extract showed more inhibitory to incident of seed mycoflora and dry mycelial weight and promoting seed germination than the other test medicinal plants. Similarly Vitex negundo, Helicteres isora, Balanites aegyptiaca were stimulatory to incidence of seed mycoflora and dry mycelial weight and inhibitory to seed germination as compared to other test medicinal plants.
\end{abstract}

Keywords: plant biomass, seed mycoflora, seedling emergence, Spinach, TPC.

\section{Introduction}

Agriculture is a back bone of our country, whole economy of India is related with agriculture. India is having the second largest population after the China. Plants are utilized as a food, clothes, shelter, medicinal, fertilizer, antimicrobial agent and many other purposes. Green manuring has been on agricultural practice among European farmers for more than two thousand years but not until the nineteenth century did students of agriculture because interested in the process by which plant material turned under became available for subsequent crops. Indian plants wealth is about 45000 plant species, every year huge waste biomass of plants going waste. It may be utilized for agriculture purposes because most of plant having antimicrobial activity.

Herbal plants are utilized for the welfare of agriculture. In the present study Total phenol content and the effect of root extract of selected medicinal plants on the incident of seed mycoflora, seed germination and growth of seed borne fungi and seedling emergence of Spinach was determined invitro. During the present studies fourteen different fungi were isolated, out of these very common four fungi brought into pure culture and effect of ten medicinal plants root extract tested on seed mycoflora, seedling emergence, sporulation and growth of seed borne fungi was determined in vitro.

\section{Materials and Methods \\ 1).Collection of seed samples:}

The method described by Neergaard (1973) has been adopted for collection of seed sample of Spinach. Seeds were collected from field, store house, market places and mixed them and used for further experiments.

\section{2) Detection of seed mycoflora:}

\section{a) Moist blotter plate method:}

The isolation of seed borne fungi was carried out by blotter test method, described by ISTA (1966), Agarwal and Sorbhoy (1978). A pair of white blotter paper of $8.5 \mathrm{~cm}$ diameter was jointly soaked in sterile distilled water and placed in presterilized petriplates of $10 \mathrm{~cm}$ diameter. 10 Seeds of Spinach were placed on equal distance on moist blotter paper. More than 400 seeds were tested for each treatment. Plates were incubated at room temp. for seven days. Identification and confirmation of different fungi on seed was made by preparing slides (Mukadam, D.S., 1997). Fourteen fungi were isolated, out of these four very common fungi brought in to the pure culture and further used.

\section{3).Collection of plant material and} preparation of plant root extract:

Ten very common and easily available plants were selected, the roots of selected plants were surface sterilized, dried in oven and ground into fine powder with the help of blender. $5 \%$ aq. 
root extract was found more effective for control of seed mycoflora of Spinach.

\section{4) Effect of root extract on growth of seed borne fungi:}

The dominant seed borne fungi of Spinach were grown in liquid GN medium supplement with $1 \mathrm{ml}$ of root extract of selected plants separately. It incubates for seven days at room temp. After incubation the content were filtered through pre-weighed Whatman filter paper no.1. The filter paper with mycelial mat was oven dried and reweighed.

\section{5) Effect of root extract on seed germination, root and shoot elongation:}

Spinach seeds were soaked separately in aq. Root extract of selected plants for $24 \mathrm{hrs}$. Soaked seeds were placed on moist blotter in presterilized petriplates. These were incubated for ten days at room temp., after incubation percent of seed germination, root and shoot length were recorded.

\section{6) Effect of root extract on seedling emergence:}

Spinach seeds were soaked separately in the aq. root extract of test plants for $24 \mathrm{hrs}$. Soaked seeds were sown at the depth of $2 \mathrm{~cm}$ equidistantly in a pot containing sterilized black soil and sand. It kept for observation for ten days and results were noted down.

7) Spore suspension: For this study $10 \mathrm{ml}$ of DW poured into the sporulating pure culture of the seed borne fungi maintained on PDA slants for 7 days at room temperature. The slants were shaken and the content was filtered through muslin cloth. The filterate was used as spore suspension.

\section{8) Total Phenol content (TPC) of the root biomass of the medicinal plants:}

TPC of the biomass of the test medicinal plants was estimated by using Folin-Ciocalteu method as described by Mahadevan and Sridhar (1996). For this $1 \mathrm{ml}$ of the alcoholic extract of biomass of the test medicinal plants was taken in a graduated test tube. $1 \mathrm{ml}$ of FolinCiocalteu reagent and $2 \mathrm{ml}$ of sodium carbonate solution was added to the test tube. The test tube was shaken and heated in a boiling water bath for exactly one minute. Test tube was cooled under running tap water. The blue colored solution in the test tube was diluted to $25 \mathrm{ml}$ with distilled water and the absorbance was measured at $650 \mathrm{~nm}$ in a colorimeter. The unknown were read from a standard curve made from different concentrations of catechol. A blank containing the entire reagent minus alcoholic extract of biomass of the test medicinal plants was used to adjust the absorbance to zero.

\section{Results and Discussion}

It is clear from result presented in the Table No. 1 that root extract of Semecarpus anacardium (15\%), Abrus precatorius (18\%) and Solanum xanthocarpum (22\%) were found more inhibitory for the incidence of seed mycoflora than the other test medicinal plants. Similar study was carried out by Bhajbhuje M. N. (2013), Amer Habib etal (2007), Mashooda and Lokesh (2008) and Saha et al (2005). Spinach seed germination stimulated by root of Abrus precatorius (86\%), Datura metel (84\%) and Semecarpus anacardium $(82 \%)$ than the other test medicinal plants. Similar results were obtained by I. Hamim et al (2014). Seedling emergence of spinach were stimulatory root biomass of Semecarpus anacardium (92\%) and Aegle marmelos (84\%) than the other test medicinal plants.

It is evident from result presented in Table No.2 that the root extract of Sapindus laurifolius (39 mg/gm) was showed more Total Phenol content (TPC) and root biomass of Helecteres isora $(25 \mathrm{mg} / \mathrm{gm})$ found very less TPC than other test medicinal plants. Selected fungal species dry mycelial weight of Fusarium found stimulatory In the root biomass of Balanites aegyptica $(70 \mathrm{mg})$, more inhibitory in Datura metel $(20 \mathrm{mg}$ ) and other showing intermediate between these test medicinal plants. Root biomass of test medicinal plants against dry mycelial weight were stimulatory effect was found in Vitex negundo and in control. Dry mycelial weight of Drechslera longirostrata was found inhibitory effect of root biomass of Aegle marmelos and Semecarpus anacardium and stimulatory in Vitex negundo $(68 \mathrm{mg} / \mathrm{gm})$ and Helecterers isora $(61 \mathrm{mg} / \mathrm{gm})$. Similarly dry mycelial weight of Fusarium monoliforme was found more inhibitory in root extract of Solanum xanthocarpum (15mg/gm) and Semecarpus anardium (19 mg/gm). 
Table No.1: Effect of test medicinal plants root extract on incidence of seed mycoflora, seed germination and seedling emergence of Spinach:

\begin{tabular}{|c|c|c|c|c|c|c|}
\hline \multirow[t]{2}{*}{ Sr. No } & \multirow[t]{2}{*}{ 5\% Root biomass } & \multirow[t]{2}{*}{ Incidence of seed mycoflora } & \multicolumn{3}{|c|}{ Seed germination } & \multirow[t]{2}{*}{ Seedling emergence } \\
\hline & & & $\%$ & RL (mm) & SL (mm) & \\
\hline 1 & Abrus precatorius L. & 18 & 86 & 35 & 42 & 81 \\
\hline 2 & Aegle marmelos $\mathrm{L}$. & 23 & 79 & 35 & 40 & 84 \\
\hline 3 & Balanites aegyptiaca Delile & 59 & 68 & 26 & 31 & 65 \\
\hline 4 & Datura metel L. & 30 & 84 & 31 & 38 & 78 \\
\hline 5 & Dioscorea bulbifera L. & 40 & 72 & 24 & 32 & 67 \\
\hline 6 & Helicteres isora L. & 65 & 57 & 23 & 28 & 59 \\
\hline 7 & Sapindus laurifolius Vahl. & 45 & 81 & 36 & 43 & 61 \\
\hline 8 & Semecarpus anacardium $\mathrm{L}$. & 15 & 82 & 39 & 48 & 92 \\
\hline 9 & Solanum xanthocarpum Schrad. & 22 & 74 & 34 & 39 & 79 \\
\hline 10 & Vitex negundo $\mathrm{L}$. & 78 & 46 & 21 & 27 & 48 \\
\hline & Control & 92 & 62 & 23 & 32 & 56 \\
\hline
\end{tabular}

$\%$ Percent, RL: Root Length, SL: Shoot Length

Table No.2: Total Phenol content and effect of root extract of test medicinal plants on the growth and sporulation of seed borne fungi of Spinach

\begin{tabular}{|c|c|c|c|c|c|c|c|c|c|c|}
\hline \multirow{2}{*}{$\begin{array}{l}\text { Sr. } \\
\text { No } \\
\text {. }\end{array}$} & \multirow[b]{2}{*}{ Root biomass $5 \%$ aq. } & \multirow{2}{*}{$\begin{array}{l}\text { TPC of } \\
\text { Root } \\
\text { biomass } \\
\text { mg/gm }\end{array}$} & \multicolumn{8}{|c|}{ Growth in terms of dry mycelial weight (mg.) } \\
\hline & & & FUM & $\underset{\mathbf{n}}{\text { Sporulatio }}$ & ALT & $\begin{array}{c}\text { Spor } \\
\text { ulati } \\
\text { on }\end{array}$ & CUL & $\begin{array}{c}\text { Sporul } \\
\text { ation }\end{array}$ & ASP & $\begin{array}{c}\text { Sporul } \\
\text { ation }\end{array}$ \\
\hline 1 & Abrus precatorius $\mathrm{L}$. & 26 & 40 & ++ & 25 & + & 45 & ++ & 25 & + \\
\hline 2 & Aegle marmelos L. & 38 & 35 & + & 35 & ++ & 35 & + & 32 & ++ \\
\hline 3 & $\begin{array}{l}\text { Balanites aegyptiaca } \\
\text { Delile }\end{array}$ & 29 & 70 & +++ & 45 & ++ & 50 & ++ & 62 & +++ \\
\hline 4 & Datura metel L. & 31 & 20 & + & 35 & + & 32 & + & 35 & + \\
\hline 5 & Dioscorea bulbifera L. & 30 & 42 & ++ & 42 & ++ & 42 & + & 43 & ++ \\
\hline 6 & Helicteres isora $\mathrm{L}$. & 25 & 60 & +++ & 62 & +++ & 40 & ++ & 62 & +++ \\
\hline 7 & Sapindus laurifolius Vahl. & 39 & 31 & + & 32 & + & 35 & + & 38 & ++ \\
\hline 8 & $\begin{array}{l}\text { Semecarpus anacardium } \\
\text { L. }\end{array}$ & 32 & 34 & ++ & 35 & + & 30 & + & 37 & ++ \\
\hline 9 & $\begin{array}{l}\text { Solanum xanthocarpum } \\
\text { Schrad. }\end{array}$ & 27 & 31 & + & 30 & + & 32 & + & 31 & + \\
\hline 10 & Vitex negundo L. & 29 & 55 & ++ & 75 & +++ & 55 & ++ & 68 & +++ \\
\hline & Control & & 82 & +++ & 80 & +++ & 75 & +++ & 70 & ++++ \\
\hline
\end{tabular}

ALT-Alternaria tenuis, CUL-Curvularia lunata, ASP- Aspergillus niger, FUM-Fusarium moniliforme

\section{References:}

Amer Habib, S.T. Sahi, M.U. Ghazanfar and S. Ali (2007): Location of seed borne mycoflora of egg plant (Solanum melongena L.) in different seed component and impact on seed germinability, Int. Journ. Of Agriculture and Biology, 1560-8530/2007/09-3-514516

Agarwal D. K. and A. K. Sorbhoy (1978): Physiological studies of four species of Fusarium pathogenic to soybean. Indian Phytopathology, 31:24-31

Bhajbhuje M. N. (2013): Biodiversity of mycoflora in storage of Solanum melongena L. seeds, Int. Journ. Of Life Sciences, 2013, Vol. 1(3): 165-181.

Bodke, S. S.; A.S. khandare; D. U. Gawai \& S.S. Wadje (2005): Screening of root extract of different plants against seed mycoflora, seed germination \& seedling emergence of Pennisetum typhoids. Burn. J. Bot. Soc. Uni. Sagar.2005, Vol. No.40:43-50.

I. Hamim, D.C. Mohanto, M.A. Sarker and M.A. Ali (2014): Effect of seed borne pathogens on germination of vegetable seeds, Journ. Of Phytopathology and pest management, Vol.1, Issue 1,1-3

Iqbal Sing \& J.S. chauhan (1973): Seed borne mycoflora of Methral (Trigonella foenum-greacum L.), Ind. Phytopathology, 25: 749-750.

ISTA (1966): International Rules of Seed Testing. 1966 Inter. Seed Test. Asso. 31:1-152.

Mahadeven, A. \& R. Shridhar (1996): Methods in physiological plant pathological, Sivakami Pub.,Chennai,(Madras),India.
Mashooda Begum \& S. Lokesh (2008): Synergistic effect of fungicides on the incidence of seed mycoflora of Okra. International Journal of Botany, 4(1): 24-32, 2008.

Mukadam, D.S. (1997): The illustrated Kingdom of Fungi (Some selected genera), Published by Akshar Ganga Prakashan, Aurangabad.

Musyimi, D.M.; J.M. Ogur \& P.M. Muema (2008): Phytochemical compounds \& antimicrobial activity of extract of Aspilia plant (Aspilia mossambicensis) wild, Intern. Journal of Botany 4(1):56-61.

Neergaard Paul (1973): Detection of seed borne pathogens by culture tests. Seed Science \& Technology, 1:217-254.

Prabha Purohit and Bohra (1999): Seed mycoflora associated with some important spices seeds. Adavances plant sciences. 1999. 12(1):195-198.

Richardson, M.J., (1990): An annotated list of seedborne diseases. Publ. by ISTA, Switzerland.

Saha D., S. Dasgupta and A. Saha (2005): Antifungal activity of some plant extract against fungal pathogen of tea (Camellina sinensis) .Pharm. Biology, V. 43(1): 87-91.

Yubedee, A.G. (1998): Role of phenol oxidase peroxidase \& total phenol content in differential resistance of Dioscorea sps. of Fusarium moniliforme. Ind. Journ. of Agri. Science. 68(10):644-646. 